\title{
Gynaecography in Premature Ovarian Failure and Ovarian Dysgenesis
}

\author{
LOUIS KREEL,* M.D., M.R.C.P., F.F.R. ; JEAN GINSBURG, † D.M. ; MICHAEL F. GREEN,
}

Summary: Gynaecography-the radiological visualiza$\checkmark$ tion of the internal female genitalia after pneumoperitoneum-is a safe and simple procedure. When taken in conjunction with the clinical and laboratory findings the results of gynaecography are often a sufficient basis for diagnosis and a plan of management in women presenting with menstrual irregularity or infertility.

\section{Introduction}

There are no simple direct biochemical tests of ovarian function. The clinician relies essentially on signs such as secondary sex characteristics, hirsutism, body build and height, or bone maturation for the diagnosis of ovarian dysfunction. The most reliable test of ovarian secretory activity is similarly indirect, being based on patterns of hormone excretion and entails serial assay of urinary hormones over a prolonged period; it is in any case available only at a few centres. Confirmation of the clinical diagnosis of ovarian dysfunction, by demonstration of morphological change, may be provided in certain instances by specialized radiological techniques. In the Stein-Leventhal syndrome, for example, gynaecography is a recognized procedure for confirming the presence of enlarged cystic ovaries (Weigen and Stevens, 1967).

We have also used gynaecography to demonstrate ovarian and uterine morphology in women presenting with menstrual irregularity or infertility and in whom there was no clinical suggestion of Stein-Leventhal type ovaries. The procedure was found to be of particular value in the diagnosis of women presenting with primary or secondary amenorrhoea, who were found to have small ovaries and in whom the clue to the cause of ovarian dysfunction was provided by gynaecography. Furthermore, a variety of intra-abdominal lesions of the genital tract, not shown clinically even on examination under anaesthetic, were found by this means.

This paper reviews our experience with the last 60 gynaecographies performed in women presenting with infertility, menstrual irregularities, or hirsutism and shows the particular diagnostic value of the technique in women with dysgenetic gonads or premature ovarian failure.

\section{Methods and Subjects}

Selection of Patients.-Patients were referred for gynaecography with one or more of the following complaints: primary amenorrhoea, secondary amenorrhoea of over two years' duration, infertility for at least three years, and severe hirsutism. Initially gynaecography was performed only after endocrine and other tests had been completed, but with increasing experience of the information provided by the procedure it was requested at an earlier stage in the investigation of these patients. In women with primary amenorrhoea or with secondary amenorrhoea of over two years' duration it is now requested soon after the first visit.

* Consultant Radiologist.

t Consultant Endocrinologist.

New End Branch of the Royal Free Hospital, London N.W.3.
Gynaecography.-Gynaecography was performed by the recognized procedure of inducing a pneumoperitoneum and then positioning the patient prone, with a $30^{\circ}$ head-down tilt and with a $10^{\circ}$ tube angulation (Bonham, Grossman, and Sidaway, 1963). In most cases one film was all that was required. Occasionally two or three films were taken to provide complete visualization of the genital tract. Those additional films were mainly required in women with small or "streak" ovaries (see Table II). Radiation exposure to the gonads was estimated at 50 milliroentgen, and since only one film was taken in the vast majority of cases with normal-sized or enlarged ovaries the radiation hazard is less than that with hysterosalpingography and is well within the accepted range for examinations in this region of the body.

Other Investigations.-Vaginal cytology, skull and chest radiographs, urinary gonadotrophins, ind tests of thyroid and adrenal function were carried out routinely. Intravenous pyelography, skeletal survey, chromosomal analysis, and other special investigations were undertaken as indicated by clinical, laboratory, and gynaecographic findings, and, subsequently, examination under anaesthetic together with laparoscopy or laparotomy if required.

\section{Results}

Of the 60 patients referred to hospital, 10 presented with primary amenorrhoea, 46 with secondary amenorrhoea, 2 predominantly with hirsutism, and 2 with infertility and regular cycles. Classification has been made into broad categories based on the radiological assessment of ovarian and uterine size (Table I).

\begin{tabular}{llllr} 
TABLE I.-Results of 60 Cases of & \multicolumn{3}{c}{ Gynaecography } \\
Findings & & & & No. \\
Normal-size ovaries and uterus & $\ldots$ & $\ldots$ & $\ldots$ & 17 \\
$\begin{array}{l}\text { Polycystic ovaries, normal uterus } \\
\text { Small ovaries, normal uterus }\end{array}$ & $\ldots$ & $\ldots$ & $\ldots$ & 23 \\
Small or streak ovaries, small uterus &. & $\ldots$ & $\ldots$ & 6 \\
Normal ovaries, small or absent uterus & $\ldots$ & $\ldots$ & 7 \\
Miscellaneous unexpected findings & $\ldots$ & $\ldots$ & $\ldots$ & 4
\end{tabular}

\section{Radiological Assessment of Ovarian and Uterine Size}

In 57 out of the last 60 cases the ovaries or ovarian streaks were clearly seen and could be measured. The uterus when present was visible in all cases. The ovaries and uterus were measured on the radiograph and the ovarian index (length $x$ breadth in $\mathrm{cm}$.) was determined in the usual way (Weigen and Stevens, 1967). Ovaries are regarded as enlarged when the index is over 15 , but there is no recognized criterion for small ovaries. An index of less than 4 probably represents pathologically small ovaries. However, in most of our cases diagnosed radiologically as having small ovaries the index was less than $2 \cdot 5$.

A real difficulty arises when no ovarian tissue is seen. This is usually technical and should not be regarded as diagnostic of absent ovaries, especially as in streak ovaries small, slightly bulbous ends to the broad ligaments are visible (Figs. 1 and 2). The absence of the uterine shadow is, on the other hand, almost diagnostic of an absent normal uterus (Fig. 4). In these circumstances evidence of a bicornuate uterus should be sought, which may appear as small lateral masses superimposed on the ovaries. The streak uterus was easily diagnosable (Fig. 1). A 
small uterus was diagnosed if the thickness of the external uterine measurement was under $2.5 \mathrm{~cm}$. An estimation of the width of the uterine shadow did not appear to be helpful, and an estimation of uterine length is not possible from gynaecography.

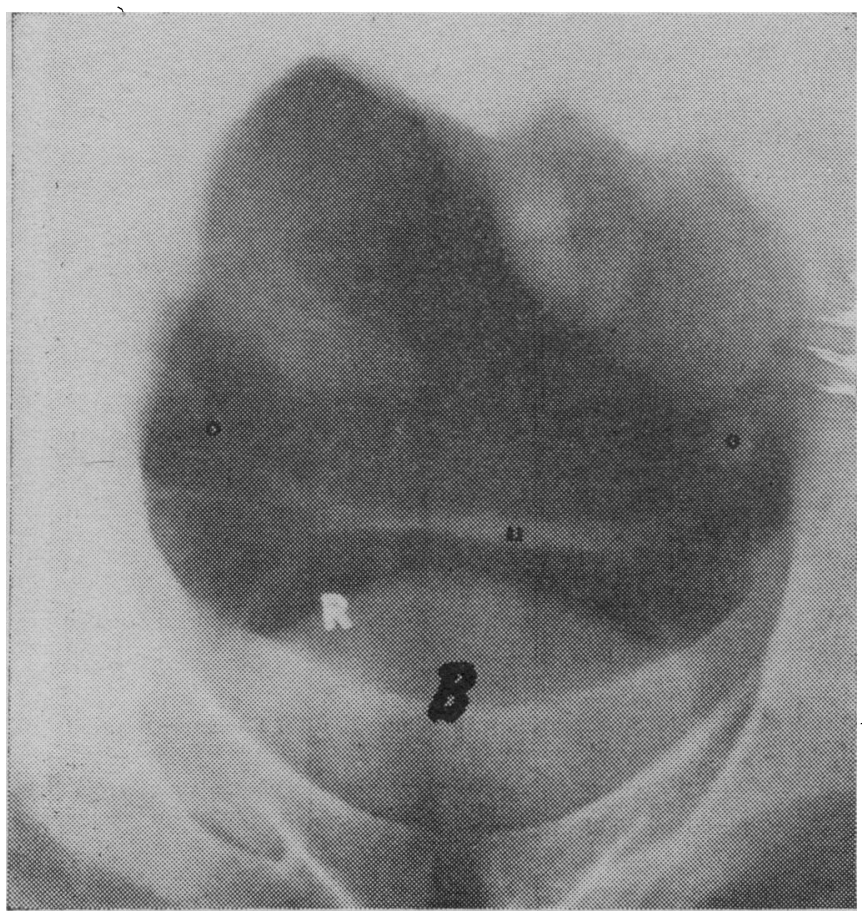

FIG. 1.-Case 2. Gynaecography showing only a genital ridge with streak ovaries and uterus $(u=$ Diminutive uterus. $\mathbf{O}=$ Ovarian streak. = Bladder shadow).

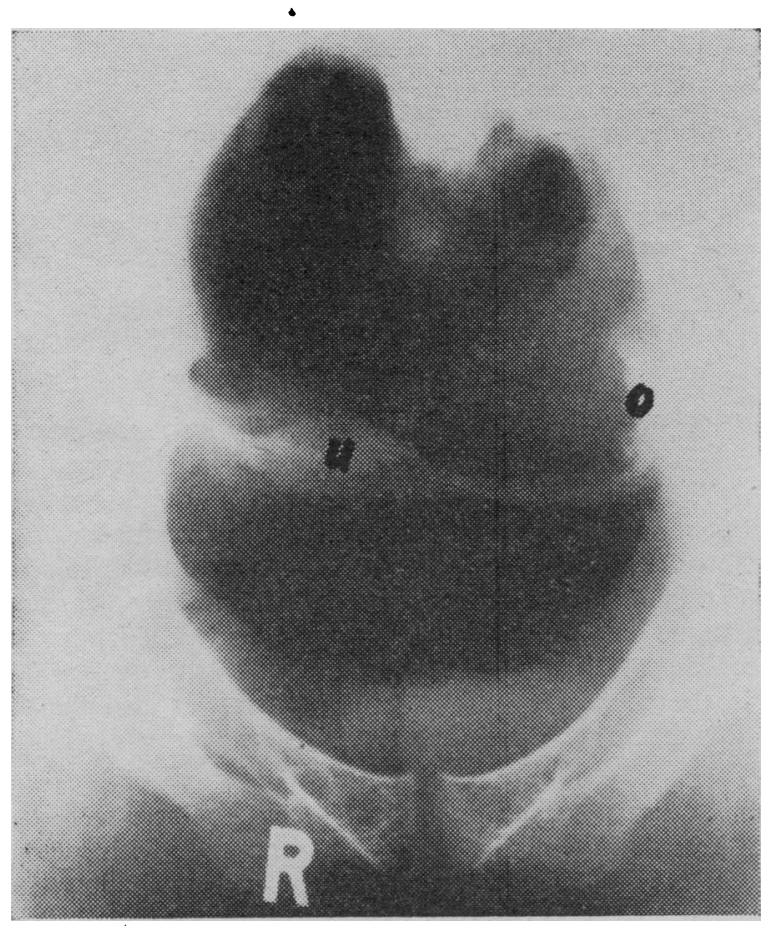

Fig. 2.-Case 5. Uterine shadow (u) is small and the left ovary shows as an elongated streak. The right ovary was not

$$
\text { visualized. }
$$

Normal-sized Ovaries and Uterus.-The 17 women in this group comprised five with hirsutism and menstrual irregularity, one with infertility and a regular menstrual pattern, one with amenorrhoea after discontinuing oral contraceptives, nine young women with secondary amenorrhoea, and one with primary amenorrhoea. No radiological abnormality of the genital tract was found in any of these women; in particular there was no evidence of ovarian cyst formation. The ovarian index ranged from 4 to 15 . Two patients recommenced menstruation after culdoscopic confirmation of the gynaecographic findings.

Polycystic Ovaries, Normal-sized Uterus.-Of the 23 women in this group, only five presented with the classical picture (obesity, amenorrhoea, and hirsutism) of the Stein-Leventhal syndrome. In 13 cases the only traditional sign was

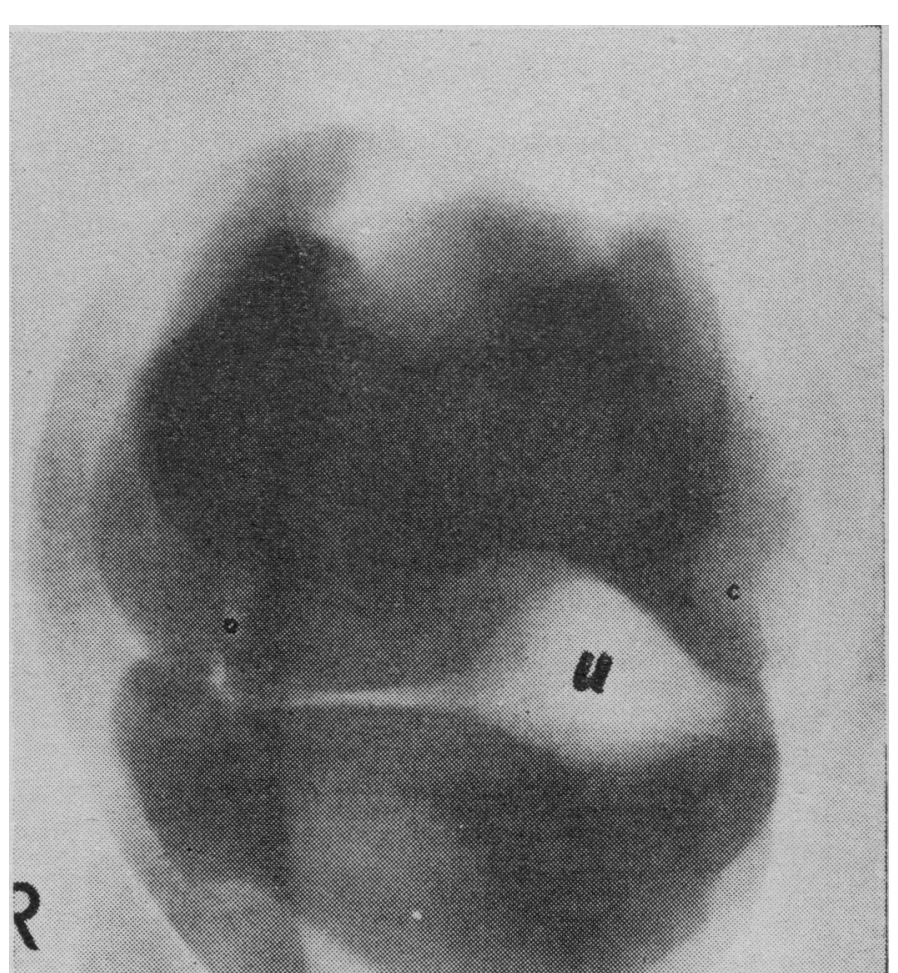

FIG. 3.-Case 11. Normal-sized uterus (u) but very small ovaries. The left ovarian shadow is smoothly rounded and circular and was a small cyst (c). The left ovary was thus only a streak.

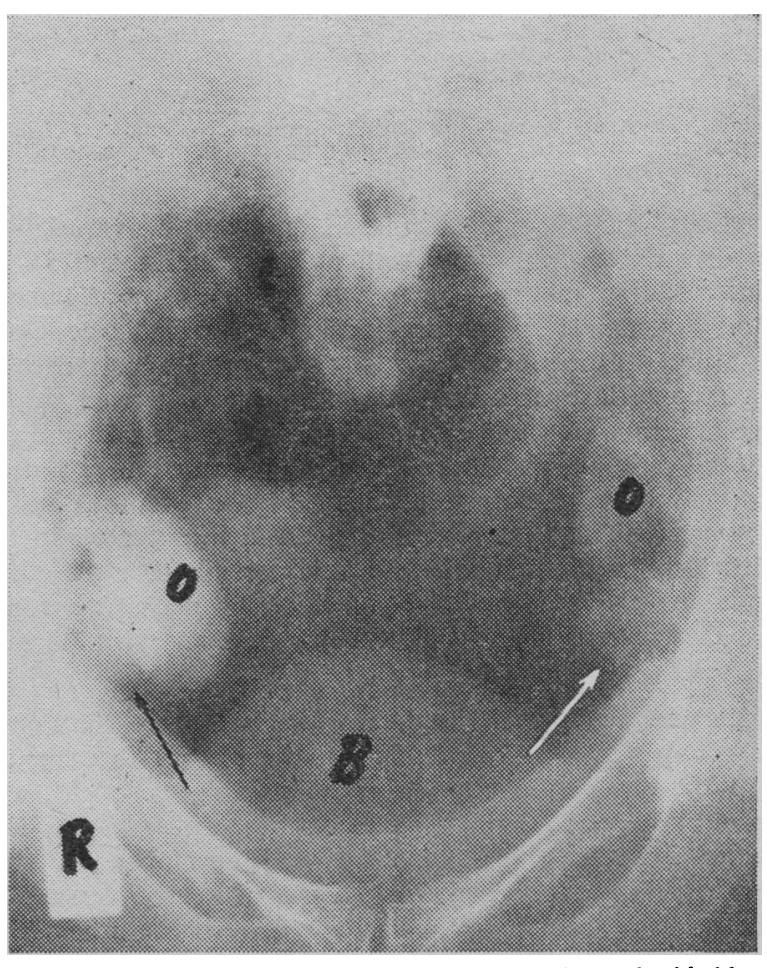

Frg. 4.-There is no normal uterine shadow above the bladder (B). Ovarian shadows (O) are present, and below these (arrows) are adjacent rounded shadows which in this case proved to be small cysts. 
TABLE II

\begin{tabular}{|c|c|c|c|c|c|}
\hline $\begin{array}{l}\text { Case } \\
\text { No. }\end{array}$ & Age & Presenting Features & Gynaecography & Karyotype and Other Investigations & Diagnosis \\
\hline 1 & 19 & $\begin{array}{l}\text { Primary amenorrhoea. Tall. Poor } \\
\text { secondary sex characters }\end{array}$ & $\begin{array}{l}\text { Genital ridge with no uterus visible, } \\
\text { streak ovaries }\end{array}$ & $\begin{array}{l}\text { 46XX. Normal gonadotrophins. Left } \\
\text { U.K., no further investigations }\end{array}$ & Gonadal dysgenesss \\
\hline 2 & 22 & $\begin{array}{l}\text { Primary amenorrhoea. Poor second- } \\
\text { ary sex characters. Short stature. } \\
\text { Idiopathic thrombocytopenic pur- } \\
\text { pura }\end{array}$ & $\begin{array}{l}\text { Minimal ovarian tissue (ovarian } \\
\text { index less than 1) demonstrable } \\
\text { on genital ridge. Uterus minute } \\
\text { (Fig. 1) }\end{array}$ & $\begin{array}{l}\text { 45XO (possibly mosaic with 46XX). } \\
\text { Raised gonadotrophins. Bone rarefac- } \\
\text { tion with delayed cpiphysial closure }\end{array}$ & Turner's syndrome \\
\hline 3 & 40 & Primary amenorrhoea. Short stature & $\begin{array}{l}\text { No real evidence of ovaries or uterus } \\
\text { on genital ridge }\end{array}$ & $\begin{array}{l}\text { Mosaic (45XO/46XX-one isochromo- } \\
\text { some). Delayed epiphysial union. Iliac } \\
\text { crest biopsy delayed ossification with } \\
\text { cxcessive cartilage. Raised gonado- } \\
\text { trophins. Past history of treated hypo- } \\
\text { thyroidism. Operative confirmation. } \\
\text { grossly hypoplastic ovaries (R. } 0 \cdot 5 \times 0 \cdot 2 \\
\text { cm., L. } 0.6 \times 0 \cdot 2 \mathrm{~cm} \text {.) and uterus } \\
(1 \times 2 \times 3 \mathrm{~cm} \text {., i.e., } 1 \mathrm{~cm} \text {. thick). No } \\
\text { germinal tissue identifiable }\end{array}$ & $\begin{array}{l}\text { Turner's syndiome } \\
\text { (mosaic) }\end{array}$ \\
\hline 4 & 21 & Primary amenorrhoea. Short stature & $\begin{array}{l}\text { No evidence of ovaries in slightly } \\
\text { widened expansions at end of } \\
\text { genital ridge. Small uterus }(2 \cdot 2 \times 3 \\
\mathrm{cm} \text {.) }\end{array}$ & $\begin{array}{l}\text { 46XX (one X isochromosome). Raised } \\
\text { gonadotrophins. Retarded bone matura- } \\
\text { tion. I.V.P. horseshoe kidney. Opera- } \\
\text { tive confirmation; macroscopically no } \\
\text { ovarian tissue identifiable, infantile } \\
\text { uterus with small atrophic tubes, horse- } \\
\text { shoe kidney identified. Histology- } \\
\text { ovarian stroma with scanty germinal } \\
\text { epithelium and embryonic tubules }\end{array}$ & Turner's syndrome \\
\hline 5 & 35 & $\begin{array}{l}\text { Primary amenorrhoea. Moderate } \\
\text { stature. Poor secondary sex charac- } \\
\text { ters }\end{array}$ & $\begin{array}{l}\text { L. ovary small, thin, and elongated } \\
(2 \times 0.5 \mathrm{~cm} \text {.). R. ovary } 1.5 \times 0.5 \\
\text { cm. Small uterus } 1 \times 2.5 \mathrm{~cm} \text {. } \\
\text { (Fig. 2) }\end{array}$ & $\begin{array}{l}\text { 46XX. Raised gonadotrophins. General- } \\
\text { ized bone rarefaction with wedged dor- } \\
\text { sal vertebrae. I.V.P. normal. Iliac crest } \\
\text { biopsy normal. Operative confirmation: } \\
\text { grossly hypoplastic uterus, Fallopian } \\
\text { tubes, and streak ovaries. Histology: } \\
\text { scanty germinal epithelium, no pri- } \\
\text { mordial follicles identifiable }\end{array}$ & Gonadal dysgenesis \\
\hline 6 & 20 & $\begin{array}{l}\text { Primary amenorrhoea. } \\
\text { secondary sex characters }\end{array}$ & $\begin{array}{l}\text { Extremely small ovaries, index } \mathrm{L} .<1 \text {, } \\
\mathrm{R} .<1 \text {. Small uterus }(2 \times 2 \mathrm{~cm} .)\end{array}$ & $\begin{array}{l}\text { 46XX. Low gonadotrophins. Awaiting } \\
\text { laparoscopy }\end{array}$ & \\
\hline 7 & 28 & $\begin{array}{l}\text { Primary amenorrhoea. Short stature, } \\
\text { obese, but normal female habitus }\end{array}$ & $\begin{array}{l}\text { Small ovaries, ovarian index } R .<3 \text {, } \\
\text { L. } 3 \text {. Uterus } 3 \cdot 2 \times 2 \mathrm{~cm} \text {. }\end{array}$ & $\begin{array}{l}\text { 46XX. Normal gonadotrophins. Normal } \\
\text { I.V.P. (small uterine bladder impres- } \\
\text { sion). Awaiting laparoscopy }\end{array}$ & ? Gonadal dysgenesis \\
\hline 8 & 29 & Secondary amenorrhoea for 13 years & $\begin{array}{l}\text { Extremely small ovaries, streak with } \\
\text { cyst. Index L. }<1, R \text { poorly } \\
\text { visualized, }<1 \text {. Uterus } 4 \times 3 \mathrm{~cm} \text {. }\end{array}$ & $\begin{array}{l}46 X X \text {. Recurrent urinary infection }(E . \\
\text { coli). I.V.P. normal. Awaiting laparo- } \\
\text { scopy }\end{array}$ & $\begin{array}{l}\text { ? Premature ovarien } \\
\text { failure }\end{array}$ \\
\hline 9 & 36 & $\begin{array}{l}\text { Secondary amenorrhoea ( } 2 \text { years) after } \\
\text { oligomenorrhoea (10 years). Wer- } \\
\text { ner's syndrome (premature ageing } \\
\text { with skin, hair, and joint changes). } \\
\text { Family history-premature greying } \\
\text { of hair }\end{array}$ & $\begin{array}{l}\text { Ovarian index R. } 3, \mathrm{~L} .2 \cdot 5 \\
\text { Uterus } 3 \times 4 \cdot 5 \mathrm{~cm} \text {. }\end{array}$ & $\begin{array}{l}\text { scopy } \\
\text { 46XX. Normal gonadotrophins. Opera- } \\
\text { tion: hard and fibrotic ovaries deroofed. } \\
\text { Histology: follicular cysts }\end{array}$ & $\begin{array}{l}\text { Werner's syndrome. Pre- } \\
\text { mature ovarian fal?ure }\end{array}$ \\
\hline 10 & 24 & $\begin{array}{l}\text { Secondary amenorrhoea (1 year) after } \\
\text { oligomenorrhoea (6 years). Meno- } \\
\text { pausal symptoms. Normal female } \\
\text { habitus }\end{array}$ & $\begin{array}{l}\text { Ovaries R. } 2 \times 0.5, \quad \text { L. } 2.5 \times 1.5 \\
\text { Uterus } 3 \times 4 \mathrm{~cm} .\end{array}$ & $\begin{array}{l}\text { 46XX Laparoscopy. R. streak ovary, L. } \\
\text { small. Biopsy from L.: follicular cysts. } \\
\text { No germinal or primordial follicles }\end{array}$ & Premature ovariar failure \\
\hline 11 & 27 & $\begin{array}{l}\text { Secondary amenorrhoea }(1 \text { year) after } \\
\text { oligomenorrhoea ( } 9 \text { years). Meno- } \\
\text { pausal symptoms. Normal female } \\
\text { habitus }\end{array}$ & $\begin{array}{l}\text { Very small ovaries (index R. } 1, \mathrm{~L} \text {. } \\
1.5 \text { with cyst). Normal uterus } \\
3.5 \times 4 \mathrm{~cm} \text {. (Fig. } 3 \text { ) }\end{array}$ & $\begin{array}{l}\text { 46XX (47XY mosaic). Raised gonado- } \\
\text { trophins. Operation: R. ovary small } \\
1.9 \times 0.4 \times 0.6 \mathrm{~cm} \text {. L. Ovary small } 1.8 \times \\
1 \times 1 \mathrm{~cm} \text {, Histology: ovaries, few } \\
\text { "atretic" follicles only in abundant } \\
\text { cellular ovarian-like connective tissue. } \\
\text { Gonadal chromosomes } 46 \mathrm{XX}\end{array}$ & $\begin{array}{l}\text { Premature ovarian failure } \\
\text { with peripheral mosaic- } \\
\text { ism, ? dysgenetic sonad }\end{array}$ \\
\hline 12 & 34 & $\begin{array}{l}\text { Secondary amenorrhoea and meno- } \\
\text { pausal symptoms (18 months) after } \\
\text { oligomenorrhoea ( } 3 \text { years) since } \\
\text { birth of second child }\end{array}$ & $\begin{array}{l}\text { Very small ovaries. Ovarian index } \\
\text { R. } 1.5 \text {, L. } 2 \times 2.5 \text { but mainly a } \\
\text { cyst. Uterus } 6 \times 5.5 \mathrm{~cm} \text {. }\end{array}$ & Awaiting laparoscopy & Premature ovarian failure \\
\hline 13 & 29 & $\begin{array}{l}\text { Secondary amenorrhoea ( } 3 \text { years) pre- } \\
\text { ceded by menorrhagia. Irregular } \\
\text { periods. Menopausal symptoms. } \\
\text { Normal female habitus }\end{array}$ & $\begin{array}{l}\text { Small cystic ovaries (index R. 3, L. } 4 \text {. } \\
\text { Uterus } 4 \times 5 \mathrm{~cm} \text {. }\end{array}$ & Awaiting laparoscopy & $\begin{array}{l}\text { ? Premature ciarian } \\
\text { failure }\end{array}$ \\
\hline
\end{tabular}

Addendum.--Since submission of this paper Laparoscopy confirmed radiological findings in Cases 6, 12, and 13 . Microsccpy: Case 6, numerous primordial follicles but few developing follicles; Cases 12 and 13, neither primordial nor developing follicles.

amenorrhoea, though typical enlarged polycystic ovaries were evident on gynaecography (ovarian index greater than 15). It is of interest that in one woman who had undergone ovarian cystectomy some 15 years previously extremely large cystic ovaries were demonstrated on gynaecography, which necessitated a second laparotomy. Laparotomy was carried out in 11 women; in each case cystic ovaries were present and the radiological estimate of ovarian size was confirmed at operation. Enlarged elongated ovaries suggestive of the Stein-Leventhal variety but with no cyst formation were demonstrated in one girl with secondary amenorrhoea. It is possible that these may represent an early stage of the condition or perhaps a forme fruste. Cysts were also found in two women with normalsized ovaries.

Small Ovaries, Normal-size Uterus.-There were six women in this group (Cases 8-13, Table II), the history in each case being of the onset of menstruation before the age of 15 , with subsequent oligomenorrhoea progressing to amenorrhoea. Secondary sex characteristics were well developed in these women. In only one patient included in this group (Case 13) was the mean ovarian index just above 3. All the others were well below. The uterus, on the other hand, was well within normal limits on gynaecography. The gynaecographic findings were confirmed at operation in two women.
Small or Streak Ovaries and Small Uterus.-Primary amenorrhoea was the presenting symptom in all seven patients (Cases 1-7, Table II). Clinical stigmata of Turner's syndrome were present in three of the women with streak gonads, but in three women of normal height and female habitus only streak gonadal tissue was demonstrable. The presence of streak ovarian tissue or of small ovaries was confirmed at laparotomy in three cases. In all except one (Case 7) the ovaries were shown to be extremely small. This patient was also the only one in this group who had a uterine shadow more than $2.5 \mathrm{~cm}$. thick.

Normal Ovaries, Small or Absent Uterus.-There were three women in this group, all of whom presented with primary amenorrhoea. In two patients no normal uterine shadow could be demonstrated and in one of these the two small lateral shadows apparent at gynaecography were shown at operation to be due to the lateral horns of a small bicornuate uterus. Laparotomy fully confirmed the gynaecographic findings of the absence of a normal uterus in these two women. In the third a small uterine shadow was confirmed at laparotomy.

Miscellaneous or Other Unexpected Findings.-A variety of unexpected lesions were found incidentally on gynaecography. In a woman with infertility of some three years' duration but with normal menstrual cycles a mass with a small calcified 
area inferiorly was apparent in the left broad ligament; this proved to be an endometrial cyst at laparotomy (see Fig. 5). Multiple myomata on the surface of the uterus were demonstrated in a woman referred with menstrual irregularity, obesity, and hirsutism (a clinical story suggestive of the SteinLeventhal syndrome) but in whom cysts were absent and ovarian size was within normal limits. Uterine myomata were also shown in a woman with a history of early miscarriage and difficulty in conception but with regular periods. None of these abnormalities had been suspected in previous gynaecological examination, even under anaesthesia. In one extremely obese woman, in whom it was not possible to outline the ovaries, there was marked increased shadowing of the broad ligament, suggesting deposition of fat in this region.

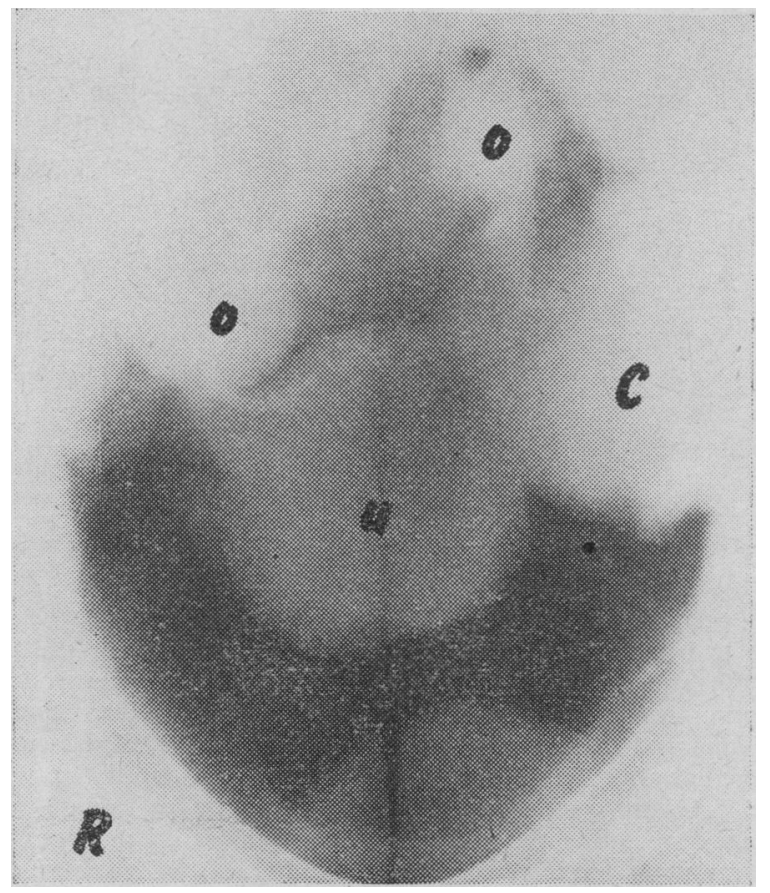

FIG. 5.- - Large cyst (c) is shown in left broad ligament. Even in this area. This case illustrates the limitations of palpatory findings.

\section{Discussion}

Our findings in polycystic ovarian disease are in general agreement with previous reports of the use of gynaecography in this condition (Short and London, 1961 ; Bonham et al., 1963 ; Weigen and Stevens, 1967) and confirm the valuable diagnostic assistance afforded by the procedure. In all cases where laparotomy was subsequently carried out the ovarian size measured at the time of operation correlated well with the preoperative radiological estimate. Clinically our series also illustrates the heterogeneity of the condition, as emphasized in many recent reviews (Prunty, 1967), enlarged polycystic ovaries often being found in the absence of the full classical clinical accompaniments of the Stein-Leventhal syndrome. Furthermore, normal ovarian size, shape, and position, as observed on gynaecography, do not necessarily exclude morbidity. The clinical findings may still indicate a need for laparoscopy or laparotomy as in one of our patients in whom a thick capsule was found at operation with histological evidence of hyperthecosis. Whether this represents a variant of the SteinLeventhal syndrome (Leventhal and Scommegna, 1963) or other morbidity requires further investigation.

The particular point of interest in this series is the number of women found to have small ovaries on gynaecography, a lesion not demonstrable or necessarily suspected on clinical grounds. Of the 60 women referred to hospital with menstrual irregularities or infertility, $13(22 \%)$ were found to have small or streak gonads. Numerically this group thus approaches those in whom enlarged polycystic ovaries were demonstrated. It is unlikely that our findings are unique in this respect, and this has also been observed by Lea Thomas, Prunty, and ${ }_{T}$ Spathis (1968) in primary amenorrhoea, but rather that gynaecography has in the past most often been requested when $\stackrel{\varnothing}{\Omega}$ enlarged ovaries were suspected on clinical grounds. Hence $c$. the frequency of this type of ovary has hitherto not been appre- $\vec{F}$ ciated and ovarian morphology in the "smaller range" not $\stackrel{P}{\rightarrow}$ stressed.

The diagnosis of classical Turner's syndrome is readily made $\frac{\bar{O}}{\bar{c}}$ on clinical examination and can be confirmed by buccal smear $\frac{\pi}{\Phi}$ and peripheral chromosomal analysis. But in other varieties $\unrhd$ of gonadal dysgenesis clinical and cytogenetic findings are variable (Kinch, Plunkett, Smout, and Carr, 1965 ; Greenblatt, $\vec{\circ}$ Byrd, McDonough, and Mahesh, 1967) and gynaecography or $\vec{\overrightarrow{ }}$ direct visualization of the ovaries by culdoscopy or laparoscopy $\vec{\sigma}$ is required for the demonstration of streak ovarian tissue. A $\frac{\partial}{\partial}$ definitive diagnosis is essential for treatment in such cases. 3 . Since the basic defect would appear to be an end-organ failure, there is nothing to be gained from stimulant therapy with, for of example, pituitary gonadotrophins. However, oestrogens of (sometimes combined with progestogens) are given to stimulate $\dot{\delta}$ breast development and alleviate menopausal symptoms and $\mathrm{N}^{\infty}$ also, prophylactically, on the grounds that this may prevent $\frac{\text { o }}{3}$ osteoporosis and the premature onset of cardiovascular disease $\overrightarrow{\mathrm{G}}$ (Kinch et al., 1965).

The risk of neoplastic change in dysgenetic gonads, especially where there is a Y line (Teter and Boczkowski, 1967), empha- $)$ sizes further the need for accurate diagnosis in cases of primary $\vec{\bullet}$ amenorrhoea. Prophylactic gonadectomy has been advocated of in women with gonadal dysgenesis, for though the incidence of malignant change in cases of Turner's syndrome with an XO karyotype is much less than in other types of ovarian dysgenesis gonadoblastomata have been reported in women with streak ovaries and an XO or normal female XX karyotype (Goldberg and Scully, 1967 ; Greenblatt et al., 1967).

Whether ovarian dysfunction in women with secondary $\overline{\bar{o}}$ amenorrhoea and small ovaries is genetically induced or 3 secondarily acquired is not known. It would appear that the distinguishing feature in most of our cases of premature ovarian failure is the size of the uterus, small ovaries in association with a small uterus suggesting a genetic defect and small ovaries together with a normal-sized uterus indicating an acquired $\dot{0}$ lesion. In men virus diseases such as mumps may induce testicular atrophy; in women oophoritis may occur but ovarian $\delta$ atrophy has not yet been established.

By analogy with other endocrine organs, such as the adrenals and the pituitary, ovarian atrophy might perhaps result from $\tilde{N}^{\circ}$ severe haemorrhage and associated hypotension, though there $D$ is as yet no evidence on this point. The possibility that the ovary may be affected in a similar manner to other endocrine organs by autoimmune processes has been suggested by the $N$ recent demonstration of antibodies to various fractions of $\omega$ ovarian tissue (Irvine et al., 1968). Thus in certain types of Addison's disease amenorrhoea or a premature menopause may occur secondary to an autoimmune process, the adrenal and ovarian failure being associated with antibodies to the $\stackrel{?}{?}$ respective tissue.

The increasing use of ovarian-stimulating agents and the $\stackrel{0}{\mathbb{D}}$

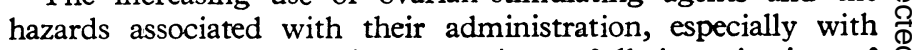
enlarged or cystic ovaries, necessitates full investigation of $\varrho$ genital structure and function when selecting patients for treatment. Gynaecography is recommended in these cases and in 8 suspected gonadal dysgenesis, at an early stage of investigation; it is a safe procedure and provides a valid assessment of ovarian and uterine size without recourse to a general anaesthetic. In fact, considerably more information may be obtained by gynaecography than from examination under anaesthesia, both of ovarian size and of genital lesions, and was well illustrated 
in two of our cases (Figs. 4 and 5). In both these patients the palpatory findings were positively misleading.

Gynaecography is not, of course, a substitute for other radiological investigations, such as hysterosalpingography, which must be carried out to determine patency of the Fallopian tubes in cases of infertility. But the results of the present study indicate the value of gynaecography as a more routine procedure in patients with infertility or menstrual irregularity. The safety and simplicity of the procedure are of particular value in the young unmarried or nulliparous patient. In many instances the gynaecographic results taken in conjunction with the clinical and laboratory findings are sufficient basis on which to plan subsequent management and the indications for hormonal or operative intervention.

It gives us great pleasure to acknowledge the invaluable help afforded by Dr. Rosalind Hurley of the Bernard Baron Laboratories, Queen Charlotte's Hospital, and by the Paediatric Research
Unit, Guy's Hospital, for the karyotype analysis, without which the diagnosis of these cases would be incomplete. We would also like to thank the photographic department of the Royal Free Hospital for the illustrations.

\section{REFERENCES}

Bonham, D. G., Grossman, M. E., and Sidaway, M. E. (1963). Clin. Radiol., 14, 356.

Goldberg, M. B., and Scully, A. L. (1967). 7. clin. Endocr., 27, 341.

Goldberg, M. B., and Scully, A. L. (1967), f. clin. Endocr., 27, 341. (1967). Amer. F. Obstet. Gynec., 98, 151.

Irvine, W. J., et al. (1968). Lancet, 2, 883.

Kinch, R. A. H., Plunkett, E. R., Smout, M. S., and Carr, D. H. (1965). Amer. $¥$. Obstet. Gynec., 91, 630 .

Lea Thomas, M., Prunty, F. T. G., and Spathis, G. S. (1968). 7. Obstet. Gynaec. Brit. Cwlth, 75, 652 .

Leventhal, M. L., and Scommegna, A. (1963). Amer. 7. Obstet. Gynec., 87, 445 .

Prunty, F. T. G. (1967). F. Endocr., 38, 203.

Short, R. V., and London, D. R. (1961). Brit. med. F., 1, 1724.

Teter, J., and Boczkowski, K. (1967). Cancer (Philad.), 20, 1301.

Weigen, J. F., and Stevens, G. M. (1967). Amer. F. Roentgenol., 100, 680.

\section{Preliminary Communications}

\section{Obstruction of Bowel due to Lesion in the Myenteric Plexus}

[With Special Plate facing Page 671]

Brit. med. F., 1969, 1, 686-689

Cummary : Two patients are described who were found $\checkmark$ to have a destructive lesion of the myenteric plexus. In one the upper small intestine was involved and the clinical picture was of recurrent pseudo-obstruction; in the other the lesion was in the distal colon and resulted in intractable constipation. The lesion cannot be demonstrated by conventional histological techniques, being seen only in silver preparations cut parallel to the bowel wall, and may have been overlooked in the past. The aetiology is unknown.

\section{INTRODUCTION}

Involvement of the autonomic nervous system is often invoked as a cause of disturbance of bowel function but is rarely confirmed by histological examination. We report two cases with a hitherto undescribed lesion of the myenteric plexus, which was demonstrated by examination of sections cut parallel to the bowel wall (Smith, 1967a). In the first case the lesion mainly involved the upper small intestine and resulted in recurrent unexplained intestinal pseudo-obstruction. The second patient had colonic involvement and presented with intractable constipation.

\section{CASE 1}

This patient gave a 19-year history of episodic unexplained intestinal obstruction. Symptoms had started at the age of 48, but there were no abnormal physical signs, though slight dilatation of the upper small intestine was shown by a barium meal. Symp- toms had been severe enough to warrant laparotomy at the ages of 56,60 , and 65 . Each time the stomach, duodenum, and upper jejunum were dilated, but no mechanical cause of obstruction could be found and the ileum was normal. During the third laparotomy hypertrophy of the wall of the bowel was described for the first time. Gastrojejunostomy and vagotomy were performed. After the third operation the abdominal symptoms failed to settle and he was found to have steatorrhoea (16-35 g. of fat excreted per 24 hours) and hypoalbuminaemia (2.8-3.2 g./100 ml.). Treatment with a gluten-free diet, steroids, and a wide variety of nutritional supplements failed to improve his condition. Five months later he developed loss of sensation in his right thigh, which was followed by progressively increasing weakness of both legs so that he had been virtually bedridden for seven months when he was transferred to this hospital. $\mathrm{He}$ was also losing weight progressively and suffering from bouts of abdominal pain, distension, and vomiting, which occurred two to three times a week.

Physical examination showed a wasted man with the skin changes of protein deficiency and moderate ankle oedema. The abdomen was distended and small-intestinal peristalsis was visible. Bowel sounds were loud and hyperactive.

Investigations showed a slight iron-deficiency anaemia (haemoglobin 10.2 g. $/ 100 \mathrm{ml}$.), hypoalbuminaemia $(2 \cdot 1-2.9$ g. $/ 100 \mathrm{ml}$.), hyponatraemia (119-130 mEq/100 ml.), and hypokalaemia (2.9$3.5 \mathrm{mEq} / 100 \mathrm{ml}$.). Barium meal and follow-through examination showed gross stasis of barium in a markedly dilated upper gastrointestinal tract. Some barium had reached the lower jejunum at seven hours (Special Plate, Fig. 1), but most of it was still retained in the stomach and proximal loop at 24 hours. This stasis presumably accounted for the heavy contamination of the jejunal fluid by aerobic and anaerobic organisms, which had caused complete hydrolysis of conjugated bile salts. Serum antibodies could not be detected against Toxoplasma gondii, and virus was not cultured from the faeces.

In view of his disability a further laparotomy was performed on 12 September 1967. The stomach was hypertrophied and enlarged. There was gross dilatation of the duodenum and jejunum, and the bowel wall was thickened. At first the involved bowel was flaccid, then segmentation movements, but not progressive contraction waves, appeared after a brief period. There was a fairly sharp transition to macroscopically normal bowel in the lower jejunum. The ileum and colon appeared normal. The third and fourth parts of the 